\title{
PCR performance of a thermostable heterodimeric archaeal DNA polymerase
}

\author{
Tom Killelea ${ }^{1,2,3}$, Céline Ralec ${ }^{1,2,3}$, Audrey Bossé ${ }^{1,2,3}$ and Ghislaine Henneke ${ }^{1,2,3 *}$ \\ 1 Université de Bretagne Occidentale, UMR 6197, Laboratoire de Microbiologie des Environnements Extrêmes, Plouzané, France \\ 2 Ifremer, UMR 6197, Laboratoire de Microbiologie des Environnements Extrêmes, Plouzané, France \\ ${ }^{3}$ CNRS, UMR 6197, Laboratoire de Microbiologie des Environnements Extrêmes, Plouzané, France
}

Edited by:

Zvi Kelman, University of Maryland, USA

\section{Reviewed by:}

Uli Stingl, King Abdullah University of Science and Technology, Saudi Arabia

Dennis W. Grogan, University of Cincinnati, USA

\section{*Correspondence:}

Ghislaine Henneke, Laboratoire de Microbiologie des Environnements Extrêmes, Ifremer, UMR 6197, ZI de la point du diable, CS 10070, 29280 Plouzané, France

e-mail: ghenneke@ifremer.fr
DNA polymerases are versatile tools used in numerous important molecular biological core technologies like the ubiquitous polymerase chain reaction (PCR), cDNA cloning, genome sequencing, and nucleic acid based diagnostics. Taking into account the multiple DNA amplification techniques in use, different DNA polymerases must be optimized for each type of application. One of the current tendencies is to reengineer or to discover new DNA polymerases with increased performance and broadened substrate spectra. At present, there is a great demand for such enzymes in applications, e.g., forensics or paleogenomics. Current major limitations hinge on the inability of conventional PCR enzymes, such as Taq, to amplify degraded or low amounts of template DNA. Besides, a wide range of PCR inhibitors can also impede reactions of nucleic acid amplification. Here we looked at the PCR performances of the proof-reading D-type DNA polymerase from $P$. abyssi, Pab-polD. Fragments, 3 kilobases in length, were specifically PCR-amplified in its optimized reaction buffer. Pab-polD showed not only a greater resistance to high denaturation temperatures than Taq during cycling, but also a superior tolerance to the presence of potential inhibitors. Proficient proof-reading Pab-polD enzyme could also extend a primer containing up to two mismatches at the $3^{\prime}$ primer termini. Overall, we found valuable biochemical properties in Pab-polD compared to the conventional Taq, which makes the enzyme ideally suited for cutting-edge PCR-applications.

Keywords: DNA polymerase, Archaea, family D, PCR, Pyrococcus

\section{INTRODUCTION}

On the basis of their amino acid sequence and structural analysis, DNA polymerases have been classified into seven families, A, B, C, D, E, X, and Y (Delarue et al., 1990; Braithwaite and Ito, 1993; Joyce and Steitz, 1994; Cann et al., 1998; Ishino et al., 1998; Ohmori et al., 2001; Lipps et al., 2003). Despite the conserved template-directed synthesis (or editing) of a complementary deoxyribonucleotide chain (Kornberg and Baker, 1992; Hubscher et al., 2010) and the similarity of the three-dimensional organization of their polymerase domain ("palm," "thumb," and "finger") (Joyce and Steitz, 1994; Rothwell and Waksman, 2005), DNA polymerases differ extensively in many of their specific features (e.g., processivity, fidelity, rate of DNA synthesis, and nucleotide selectivity) (Hubscher et al., 2010; Langhorst et al., 2012).

Beginning with the discovery and characterization of DNA polymerase I (Family A) from Thermus aquaticus (Taq) (Chien et al., 1976), a variety of thermostable DNA polymerases have been isolated and identified from prokaryotic organisms. Besides their crucial biological functions, thermostable DNA polymerases have proven to be technically and economically important enzymes. They are versatile tools used in DNA technologies such as cycle sequencing and polymerase chain reaction (PCR) (Pavlov et al., 2004). Since its invention by Saiki et al. (1985), PCR has become a widespread molecular biology method. Originally
PCR was developed to specifically amplify a stretch of DNA prior to cloning; however, its flexibility underpins a number of applications such as site-directed mutagenesis, genetic diagnostics, gene therapy, forensics, and paleogenomics.

In the PCR, DNA amplification is performed by thermostable enzymes; invariably either family A DNA polymerases from thermophilic and hyperthermophilic Bacteria (e.g., Thermus aquaticus, Taq-polA and Thermotoga maritima, Tma-polA) or family B DNA polymerases from hyperthermophilic Archaea (e.g., Pyrococcus furiosus, Pfu-polB and Pyrococcus abyssi, Pab-polB; Isis $\left.{ }^{\mathrm{TM}}\right)$. Family $\mathrm{Y}$ DNA polymerase from the hyperthermophilic archaeon Sulfolobus solfataricus, Sso-polY, is also an enzyme marketed for PCR, but with specialist applications (McDonald et al., 2006). Each thermostable DNA polymerases has different characteristics (e.g., thermostability, processivity, fidelity, specificity, modified nucleotides selection, resistance to contaminants and inhibitors, slippage, pyrophosphorolysis) and to achieve optimal results, the choice of a PCR enzyme depends on the application itself (e.g., high-yield PCR, high-fidelity PCR, routine PCR, multiplex PCR, colony PCR, difficult PCR, long Range PCR, fast PCR, incorporation of modified nucleotides). Detailed information about individual properties of PCR enzymes and their related applications have been recently reviewed (Terpe, 2013). 
Archaeal family B DNA polymerases are generally more thermostable enzymes than bacterial polymerases (Kong et al., 1993; Takagi et al., 1997; Cambon-Bonavita et al., 2000; Gueguen et al., 2001; Hogrefe et al., 2001; Moussard et al., 2006; Marsic et al., 2008). In addition, when accuracy is a desired property it leads to a preference for archaeal enzymes which possess a $3^{\prime}-5^{\prime}$ proof-reading exonuclease activity, absent in most thermostable bacterial polymerases (Eckert and Kunkel, 1991; Cline et al., 1996; Perler et al., 1996). On the other hand, archaeal family B DNA polymerases can incorporate dUTP during DNA replication but cannot copy these strands in subsequent DNA amplification rounds (Fogg et al., 2002). With constant development of new techniques based on PCR, improved DNA polymerase variants are continuously being engineered including: polymerases which are thermo-activated (hot start polymerases) (Sharkey et al., 1994), bacterial and archaeal DNA polymerase derivatives with increased processivity (Wang et al., 2004), archaeal family B DNA polymerase variants insensitive to uracil inhibition (Fogg et al., 2002), or thermostable enzymes proficient in the synthesis of fluorescent CyDNAs (Ghadessy et al., 2004; Wynne et al., 2013). Error-prone PCR which creates random mutagenesis of the parental gene relies on different strategies using either lowfidelity DNA polymerase variants (Biles and Connolly, 2004) or error-prone PCR conditions (McCullum et al., 2010; Le et al., 2013). Most of these conventional marketed PCR enzymes have the drawback of replicating exclusively native DNAs. Among thermostable DNA polymerases that can counteract this major limitation, archaeal translesional family Y DNA polymerases are of particular interest. They are able to bypass a variety of DNA lesions and therefore are well-suited for the PCR amplification of ancient and damaged DNAs (McDonald et al., 2006).

Over 14 years ago a new family of archaeal DNA polymerases (the D-family) was discovered (Uemori et al., 1997). Despite obvious interest in the biochemical characteristics of archaeal family D DNA polymerases (Cann et al., 1998; Gueguen et al., 2001) there is limited information regarding the structure (Yamasaki et al., 2010; Matsui et al., 2011) and kinetics of these enzymes (Palud et al., 2008; Richardson et al., 2013a). However, it is known that these thermostable DNA polymerases are heterodimeric and comprise a small subunit (DP1), possessing $3^{\prime} \rightarrow 5^{\prime}$ exonuclease activity, and a large subunit (DP2), exhibiting DNA polymerase activity (Cann and Ishino, 1999). The small subunit shares low level of homology with the non-catalytic B-subunits of the eukaryotic family B DNA polymerases (Cann et al., 1998; Ishino et al., 1998; Gueguen et al., 2001). In contrast, the sequence of the large subunit shows no significant homology to any other DNA polymerase (Macneill et al., 2001). Currently, the growing body of evidence suggests involvement of the family D DNA polymerases in genome replication in Archaea (Henneke et al., 2005; Rouillon et al., 2007; Castrec et al., 2009; Cubonova et al., 2013).

Family D DNA polymerases from hyperthermophilic Archaea which have been biochemically characterized, to date, are from the Pyrococcus genus such as Pyrococcus horikoshii (Shen et al., 2001), Pyrococcus furiosus (Uemori et al., 1997), and Pyrococcus abyssi (Gueguen et al., 2001). These microorganisms contain only one family B enzyme in addition to the family D DNA polymerase. In contrast with commercialized family B enzymes
(Pfu-polB and Pab-polB), none of the family D DNA polymerases have been reported as active enzymes in PCR or in other DNA technologies.

Family D DNA polymerase from Pyrococcus abyssi shows comparable nucleotide selectivity to family $\mathrm{B}$, and increased fidelity with the active proofreading (Palud et al., 2008; Richardson et al., 2013a). Family D DNA polymerase preferentially binds to primer/template with an affinity higher than family $B$, while showing reduced DNA synthesis of smaller DNA fragments (Henneke et al., 2005). The assembly of the two subunits into a heterodimer is required to substantially increase both polymerase and exonuclease activities in family $\mathrm{D}$, while both activities are contained within the same polypeptide in the family B DNA polymerase (Castrec et al., 2010; Gouge et al., 2012). These functional properties suggest that family D DNA polymerase might perform PCR performance distinct than Pab-polB. In this paper, the ability of the recombinant family D DNA polymerase from Pyrococcus abyssi (Pab-polD) to PCR-amplify DNA has been developed in terms of biochemical and PCR performance parameters (e.g., stability to heat denaturation steps, extension efficiency, resistance to common PCR inhibitors). These results are compared with data acquired from commercial thermostable DNA polymerases (Pab-polB and Taq-polA) and reveal that family D DNA polymerase has significant commercial value in PCR technology.

\section{MATERIALS AND METHODS CHEMICALS AND ENZYMES}

Unlabeled dNTPs were purchased from MP Biomedicals. PabpolD was cloned, expressed, and purified as described (Henneke et al., 2005). One unit of Pab-polD corresponds to the incorporation of $1 \mathrm{nmol}$ of total dTMP into acid precipitable material per minute at $65^{\circ} \mathrm{C}$ in a standard assay containing $0.5 \mathrm{mg}$ (nucleotides) of poly $(\mathrm{dA}) /$ oligo $(\mathrm{dT})_{10: 1}$. Pab-polB (Isis DNA polymerase) and Taq-polA (Taq DNA polymerase) were purchased from MP biomedicals. All other chemicals and bioreagents were analytical grade and purchased from Sigma-Aldrich (St. Louis, MO). Bioactive small molecules (Human hemoglobin, humic acid, hematin, heparin, and urea) were molecular biology grade from Sigma-Aldrich (St. Louis, MO). The 1.7 million basepair genome of Pyrococcus abyssi GE5 was obtained as described (Charbonnier et al., 1995).

\section{POLYMERASE CHAIN REACTION (PCR ENZYMES)}

PCR primers for the amplification of targets in genomic DNA from $P$. abyssi $(\mathrm{Pab})$ genomic sequence from 1323272 to 1333272 base pairs (bp) were purchased from Eurogentec (Belgium). The primer sequences, the $P a b$ genomic sequence, and the size of the expected amplicons (in kilobases, $\mathrm{kb}$ ) are summarized in Table 1. These selective amplifications were dictated by the availability of total genomic DNA from P. abyssi devoid of any potential PCR inhibitors and the use of thermally stable oligonucleotide primers. PCR performance parameters of Pab-polD were determined in the optimized buffer: $20 \mathrm{mM}$ Tris- $\mathrm{HCl} \mathrm{pH} \mathrm{9,} 25 \mathrm{mM}$ $\mathrm{KCl}, 10 \mathrm{mM}\left(\mathrm{NH}_{4}\right)_{2} \mathrm{SO}_{4}, 2 \mathrm{mM} \mathrm{MgCl} 2,0.1 \mathrm{mg} / \mathrm{ml}$ Bovine Serum Albumin (BSA), 0.1\% (v/v) Tween 20. PCR reactions $(25 \mu \mathrm{l})$ contained $200 \mathrm{nM}$ of each primer, $200 \mu \mathrm{M}$ dNTPs, and $100 \mathrm{ng}$ 
Table 1 | Primers applied in this study.

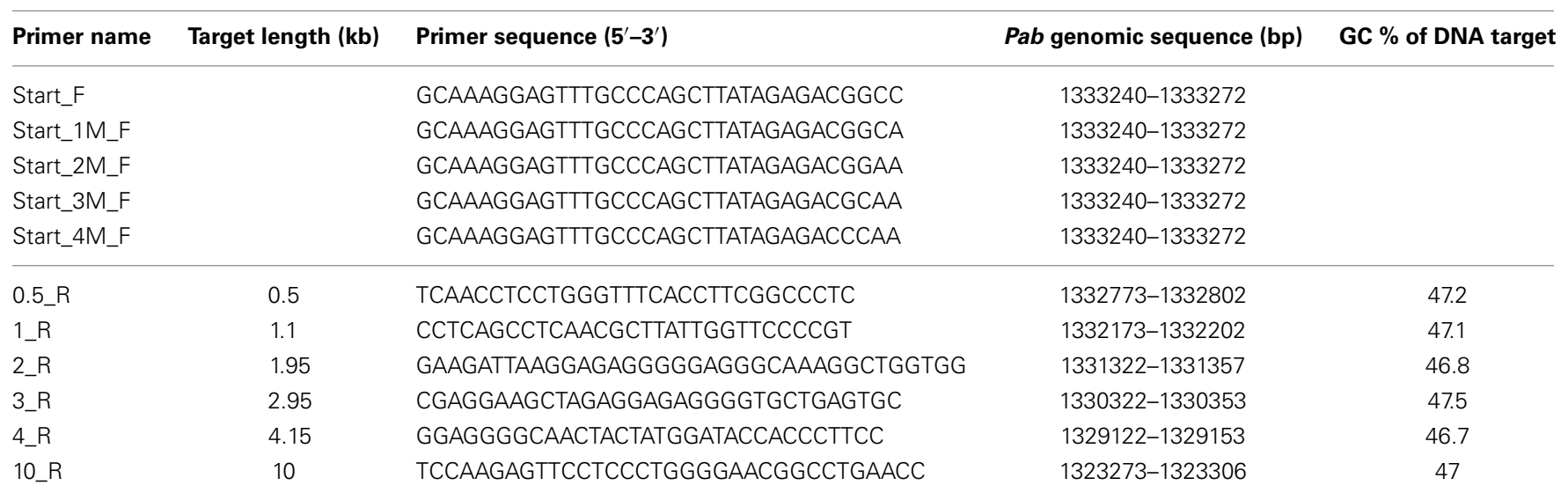

$F$ and $R$ denote forward and reverse primers, respectively. $M$ stands for mismatch.

of genomic DNA unless otherwise specified. The PCR conditions for commercial Taq-polA and Pab-polB were set according to the manufacturers' instructions. All reactions were run in (at least) duplicate. Negative control included all reaction components without genomic DNA. The amplification was carried out in GeneAmp ${ }^{\circledR}$ PCR System 9700 Thermal Cycler (Applied Biosystems) and in Veriti ${ }^{\circledR}$ 96-Well Thermal Cycler (Applied Biosystems). Cycling conditions were $2 \mathrm{~min}$ at $94^{\circ} \mathrm{C} ; 30$ cycles with $1 \mathrm{~min}$ denaturation at $94^{\circ} \mathrm{C}, 1 \mathrm{~min}$ annealing at $58^{\circ} \mathrm{C}$ and extension at $72^{\circ} \mathrm{C}$ at the indicated times. A final extension step at $72^{\circ} \mathrm{C}$ was applied before the termination of the reaction as specified in the corresponding figure legends. Elongation temperature was set at $72^{\circ} \mathrm{C}$ according to the manufacturer protocols for TaqPolA and Pab-polB, therefore validating the temperature of assay performance by Pab-polD. The products were analyzed with $1 \%$ agarose gel electrophoresis, stained with ethidium bromide, and visualized with the Molecular Imager FX (BioRad). When mentioned, activity (\%) is expressed as a percentage of the maximal value obtained in each experiment.

PCR experiments in the presence of inhibitors were conducted with the optimized Pab-polD buffer as described above. The PCR conditions for Pab-polB and Taq-polA were set according to the manufacturers' instructions. A $0.5 \mathrm{~kb}$ fragment was amplified from Pab genomic DNA using the $500 \mathrm{bp}$ reverse and forward primers (listed in Table 1). Titration of each inhibitor was performed at least in triplicate. Cycling conditions were $2 \mathrm{~min}$ at $94^{\circ} \mathrm{C}$; 30 cycles with $1 \mathrm{~min}$ denaturation at $94^{\circ} \mathrm{C}, 1 \mathrm{~min}$ annealing at $58^{\circ} \mathrm{C}$, and $2 \mathrm{~min}$ extension at $72^{\circ} \mathrm{C}$; final extension, $5 \mathrm{~min}$ at $72^{\circ} \mathrm{C}$. The products were analyzed with $1 \%$ agarose gel electrophoresis, stained with ethidium bromide, and visualized with the Molecular Imager FX (BioRad).

\section{RESULTS}

\section{OPTIMIZED PCR REACTION CONDITIONS}

The optimized buffer for PCR with Pab-polD was obtained by varying different components of the standard Pab-polB reaction buffer. Pab-polD PCR activity was optimal in $10-30 \mathrm{mM}$ Tris- $\mathrm{HCl}$ buffer concentration (Figure 1A) and between $\mathrm{pH} 8.3$ and 9 (measured at $25^{\circ} \mathrm{C}$ ) (Figure 1B). Incubation of Pab-polD with either magnesium chloride $\left(\mathrm{MgCl}_{2}\right)$ or magnesium sulfate $\left(\mathrm{MgSO}_{4}\right)$ in the same concentration range resulted in the amplification of non-specific and undesirable PCR products with $\mathrm{MgSO}_{4}$ (Figure 1C). Reactions carried out with $\mathrm{MgCl}_{2}$ gave rise to the amplification of specific products in the optimal concentration range tested (Figure 1D). The effects of different salt concentrations of potassium chloride (KCl) (Figure 1E) and ammonium sulfate $\left(\left(\mathrm{NH}_{4}\right)_{2} \mathrm{SO}_{4}\right)$ (Figure $\left.1 \mathbf{F}\right)$ were analyzed in PCR by Pab-polD. The maximal activity detected with the two salts was $0-20 \mathrm{mM}$ for $\mathrm{KCl}$ and $15-25 \mathrm{mM}$ for $\left(\mathrm{NH}_{4}\right)_{2} \mathrm{SO}_{4}$, respectively. Although the presence of $\left(\mathrm{NH}_{4}\right)_{2} \mathrm{SO}_{4}$ further enhanced PCR amplification at optimal concentration, $\mathrm{KCl}$ could be dispensable. Finally, the two additives, Tween and BSA, used in the standard Pab-polB reaction buffer were added or omitted in PabpolD PCR reactions. In the conditions tested, $0.1 \mathrm{mg} / \mathrm{ml} \mathrm{BSA}$ and $0.1 \%$ Tween did not significantly improved the amount of PCR products by Pab-polD (Figure 1G). Overall, the optimal reaction buffer for in vitro amplification of DNA fragments by Pab-polD has been determined and is now available in Table 2.

\section{EFFECT OF INPUT GENOMIC DNA ON PCR EFFICIENCY AND SPECIFICITY}

PCR amplification, targeting the $0.5 \mathrm{~kb}$ fragment in the $1.7 \mathrm{mil}$ lion base-pair genome of $P$. abyssi (Table 1), was employed to determine the minimal amount of DNA required. In its optimal reaction conditions, Pab-polD was able to specifically amplify the $0.5 \mathrm{~kb}$ target from 0.5 to $100 \mathrm{ng}$ of input genomic DNA (Figure 2A). Although the yield of PCR products was severely reduced at $0.5-1 \mathrm{ng}$, all three enzymes retained polymerase activity ( $2-5 \%$ of activity) (Figures $2 \mathrm{~A}-\mathrm{C}$ ). In the presence of $0.1 \mathrm{ng}$, only Pab-polB was capable of amplification of the $0.5 \mathrm{~kb}$ DNA target (Figure 2B).

\section{IMPACT OF THERMAL DENATURATION DURING CYCLING}

The resistance of Pab-polD to the temperature of the denaturation step during cycling was investigated in comparison with Taq-polA and Pab-polB. PCR amplifications of the $0.5 \mathrm{~kb}$ DNA target were performed with 4 different thermal denaturation steps during cycling $\left(91,95,97\right.$, and $\left.99^{\circ} \mathrm{C}\right)$. As shown in Figure 3A, 

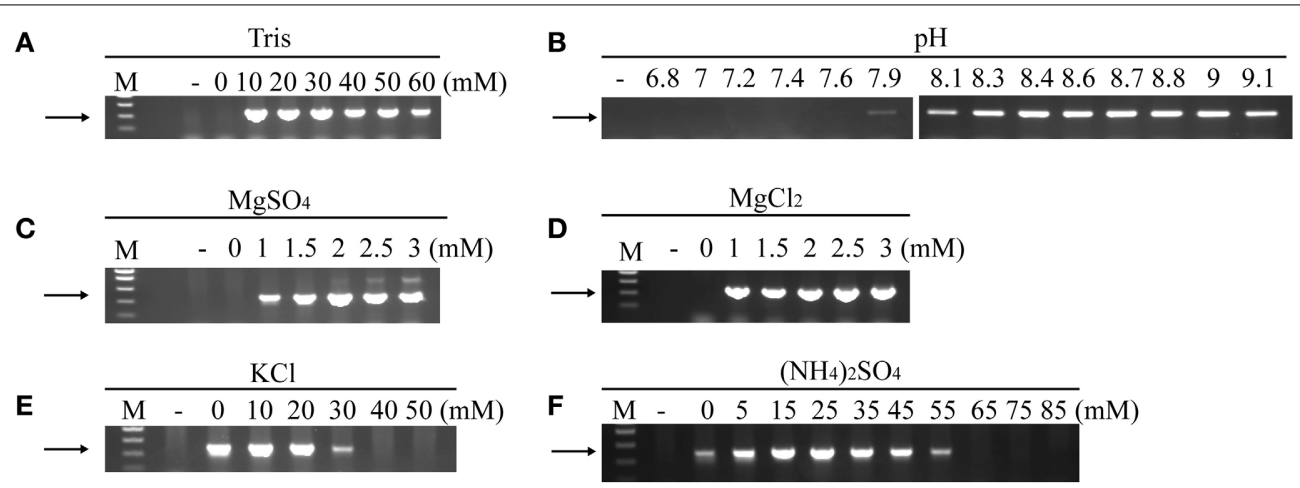

G

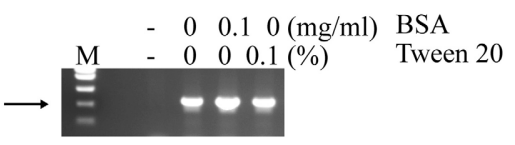

FIGURE 1 | Effect of buffer concentration, pH, salts, ions, BSA, and Tween 20 on PCR amplification of the $\mathbf{0 . 5} \mathbf{~ k b}$ target by Pab-polD. PCR reactions were carried out using $100 \mathrm{ng}$ of genomic DNA with $0.1 \mathrm{U}$ of Pab-polD. The optimized reaction buffer was used as is shown in

Table 2, except for the variable condition, which was altered as shown in the figure. PCR program was $\left(2 \mathrm{~min}\right.$ at $\left.94^{\circ} \mathrm{C}\right) \times 1$; $\left(1 \mathrm{~min}\right.$ at $94^{\circ} \mathrm{C}$,
$1 \mathrm{~min}$ at $58^{\circ} \mathrm{C}, 2 \mathrm{~min}$ at $\left.72^{\circ} \mathrm{C}\right) \times 30 ;\left(5 \mathrm{~min}\right.$ at $\left.72^{\circ} \mathrm{C}\right) \times 1$. Effect of varying the Tris concentration (A), $\mathrm{pH}$ (B), $\mathrm{MgSO}_{4}$ (C), $\mathrm{MgCl}_{2}$ (D), $\mathrm{KCl}$ (E), $\left(\mathrm{NH}_{4}\right)_{2} \mathrm{SO}_{4}(\mathbf{F})$. The absence or presence of BSA and Tween 20 are shown in (G). Molecular weight markers (M) are SmartLadder SF from Eurogentec. (-) denotes negative control without Pab-polD. The arrow indicates the specific $0.5 \mathrm{~kb}$ band.

Table 2 | Properties of experimental thermophilic DNA polymerases.

\begin{tabular}{|c|c|c|c|}
\hline & Pab-polD & Pab-polB & Taq-polA \\
\hline Name & Pab-polD & Isis & Taq \\
\hline Microorganism & Pyrococcus abyssi & Pyrococcus abyssi & Thermus aquaticus \\
\hline Pol family & $\mathrm{D}$ & $\mathrm{B}$ & A \\
\hline Half-life & $\begin{array}{l}90^{\circ} \mathrm{C} / 50 \mathrm{~min} \text { (Gueguen et al., 2001) } \\
80^{\circ} \mathrm{C} / 2 \mathrm{~h} \text { (Gueguen et al., 2001) }\end{array}$ & $\begin{array}{l}100^{\circ} \mathrm{C} / 5 \mathrm{~h} \\
90^{\circ} \mathrm{C} / 10 \mathrm{~h} \\
\text { (Gueguen et al., 2001; Dietrich et al., } \\
2002 \text { ) }\end{array}$ & $\begin{array}{l}97.5^{\circ} \mathrm{C} / 9 \mathrm{~min} \text { (Lawyer et al., 1993; } \\
\text { Perler et al., 1996) }\end{array}$ \\
\hline $\begin{array}{l}\text { Error rate } \times 10^{-6} \\
\text { (/bp/duplication) }\end{array}$ & N.P. & 0.66 (Dietrich et al., 2002) & 24 (Dietrich et al., 2002) \\
\hline Reaction buffer & $\begin{array}{l}20 \mathrm{mM} \text { Tris- } \mathrm{HCl}, \mathrm{pH}\left(25^{\circ} \mathrm{C}\right) 9.0,25 \mathrm{mM} \\
\mathrm{KCl}, 10 \mathrm{mM}(\mathrm{NH} 4)_{2} \mathrm{SO}_{4}, 2 \mathrm{mM} \mathrm{MgCl} \\
0.1 \% \text { Tween } 20,0.1 \mathrm{mg} / \mathrm{ml} \mathrm{BSA}\end{array}$ & $\begin{array}{l}20 \mathrm{mM} \text { Tris- } \mathrm{HCl}, \mathrm{pH}\left(25^{\circ} \mathrm{C}\right) 9.0,25 \mathrm{mM} \\
\mathrm{KCl}, 10 \mathrm{mM}(\mathrm{NH} 4)_{2} \mathrm{SO}_{4}, 1.5 \mathrm{mM} \mathrm{MgSO}_{4} \\
0.1 \% \text { Tween } 20,0.1 \mathrm{mg} / \mathrm{ml} \mathrm{BSA}\end{array}$ & $\begin{array}{l}10 \mathrm{mM} \text { Tris- } \mathrm{HCl} \mathrm{pH}\left(25^{\circ} \mathrm{C}\right) \text { 9.0, } 50 \mathrm{mM} \\
\mathrm{KCl}, 1.5 \mathrm{mM}, \mathrm{MgCl}_{2}, 0.2 \mathrm{mg} / \mathrm{mL} \mathrm{BSA}\end{array}$ \\
\hline $\begin{array}{l}\text { Exonuclease } \\
\text { activities }\end{array}$ & 3'-5' (Gueguen et al., 2001) & $3^{\prime}-5^{\prime}$ (Gueguen et al., 2001) & 5'-3' (Lawyer et al., 1993) \\
\hline $\begin{array}{l}\text { Extension rate: } \\
\mathrm{kb} / \mathrm{min}(\mathrm{nt} / \mathrm{s})\end{array}$ & $0.33(5.5)$ & $0.48(8)$ & $0.39(6.5)$ \\
\hline
\end{tabular}

N.P., Not Published.

Error rate for Pab-polB and Taq-polA were determined in the same experiments under the same conditions (Dietrich et al., 2002).

Pab-polD could yield specific PCR products (15\% activity compared to $91^{\circ} \mathrm{C}$ ) when the denaturation temperature was as high as $97^{\circ} \mathrm{C}$. PCR products were hardly detectable at $99^{\circ} \mathrm{C}$. Interestingly, the PCR efficiency of Pab-polB was not profoundly affected by the increase in the thermal denaturation step during cycling, while Taq-polA was mostly inactive above $95^{\circ} \mathrm{C}$ (Figures 3B,C). Taken together, these results are in agreement with those published previously (Dietrich et al., 2002) and indicate that hyperthermophilic Pab DNA polymerases are more robust than the thermophilic Taq-polA.

\section{RATE OF DNA EXTENSION}

In order to determine the rate of primer extension by Pab-polD, the $1.95 \mathrm{~kb}$ DNA target was amplified using variants of the endpoint PCR method employed throughout this study. Numerous reactions were carried out, with each PCR possessing an incrementally larger extension time than the last, until end-point PCR products were detectable on an agarose gel. Our initial attempt, in which the longest extension time was set to $240 \mathrm{~s}$, failed with Pab-polD and Taq-polA (Figures 4A,C). However, the $1.95 \mathrm{~kb}$ DNA target was successfully amplified 


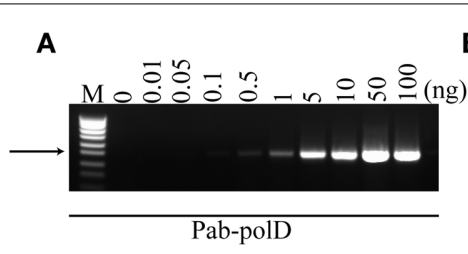

B $\quad$ C

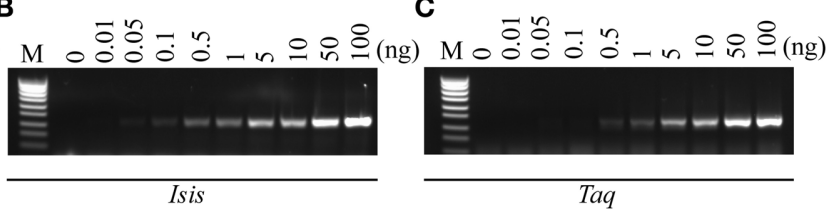

FIGURE 2 | Effect of input genomic DNA on PCR efficiency and specificity. PCR amplification of the $0.5 \mathrm{~kb}$ target (Table 1) was carried out with $0.1 U$ of Pab-polD (A), $1 U$ of Pab-polB (B), and $1 U$ of Taq-polA (C) in their respective reaction buffer (Table 2). PCR program was $\left(2 \mathrm{~min}\right.$ at $\left.94^{\circ} \mathrm{C}\right) \times 1$; $\left(1 \mathrm{~min}\right.$ at $94^{\circ} \mathrm{C}, 1 \mathrm{~min}$ at $58^{\circ} \mathrm{C}, 2 \mathrm{~min}$ at $\left.72^{\circ} \mathrm{C}\right) \times 30 ;\left(5 \mathrm{~min}\right.$ at $\left.72^{\circ} \mathrm{C}\right) \times 1$. Molecular weight markers $(\mathrm{M})$ are SmartLadder SF from Eurogentec. The arrow indicates the specific $0.5 \mathrm{~kb}$ band.

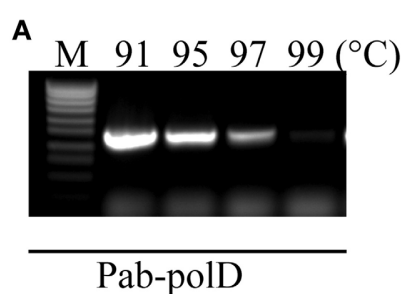

Pab-polD

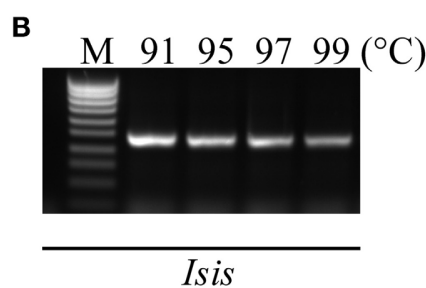

Isis

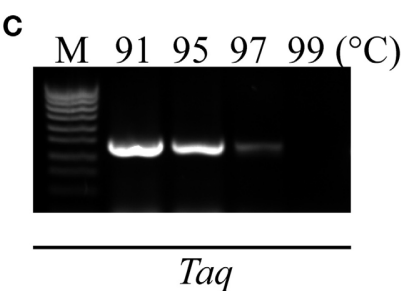

Taq
FIGURE 3 | Impact of thermal denaturation during cycling. PCR amplification of the $0.5 \mathrm{~kb}$ target (Table 1) was carried out with $0.1 \mathrm{U}$ of Pab-polD (A), $1 \cup$ of Pab-polB (B), and $1 U$ of Taq-polA (C) in their respective reaction buffer (Table 2). PCR program was $\left(2 \mathrm{~min}\right.$ at $\left.94^{\circ} \mathrm{C}\right) \times 1 ;(1 \mathrm{~min}$ at the indicated temperature, $1 \mathrm{~min}$ at $58^{\circ} \mathrm{C}, 2 \mathrm{~min}$ at $\left.72^{\circ} \mathrm{C}\right) \times 30$; $\left(5 \mathrm{~min}\right.$ at $\left.72^{\circ} \mathrm{C}\right) \times 1$. Molecular weight markers (M) are SmartLadder SF from Eurogentec. by Pab-polB (Figure 4B). Pab-polD exhibited a lower extension rate than Taq-polA since a single specific product at the expected size appeared at 360 and $300 \mathrm{~s}$, respectively for each enzyme. According to these results, the rate of extension by PabpolD was estimated at $0.33 \mathrm{~kb} / \mathrm{min}$, resembling that of Taq-polA $(0.39 \mathrm{~kb} / \mathrm{min})$, but dissimilar to that of Pab-polB $(0.48 \mathrm{~kb} / \mathrm{min})$ (Table 2).

\section{PCR AMPLIFICATION OF DNA FRAGMENTS OF VARIOUS LENGTHS}

To determine the ability of Pab-polD to amplify various sized target sequences (ranging 0.5 to $10 \mathrm{~kb}$ ) from genomic DNA, six specific primers have been designed (Table 1). The extension time assigned to the amplification of each DNA fragment during cycling is in agreement with the extension rate of PabpolD described above. In the range of $0.5-1.1 \mathrm{~kb}, \mathrm{Pab}-\mathrm{polD}$ and Taq-polA efficiently and specifically amplified DNA fragments (Figures 5A,C). Amplification of DNA molecules ranging from 1.95 to $2.95 \mathrm{~kb}$ was severely reduced for Pab-polD and to lower extent for Taq-polA ( $\sim 8 \%$ activity for the $2.95 \mathrm{~kb}$ target compared with the $0.5 \mathrm{~kb}$ target for both DNA polymerases), with bands at these sizes being faint and slightly detectable in ethidium bromide stained agarose gels after 30 PCR cycles. Amplification of target sequences ranging from 4.15 to $10 \mathrm{~kb}$ by Pab-polD and Taq-polA failed in the conditions tested (Figures 5A,C), with Pab-polD producing weak and unspecific bands. With the exception of the 4.15 and $10 \mathrm{~kb}$ DNA targets, Pab-polB amplified single products with the expected size (Figure 5B). Except for the $10 \mathrm{~kb}$ DNA target, a single product was amplified with Pab-polB. However, the yield of specific PCR products is decreased for the $2.95 \mathrm{~kb}$ DNA target. The above data clearly show that Pab-polD is suitable for the specific amplification of DNA molecules in the range of $0.5-2.95 \mathrm{~kb}$, while showing reduced yields above $1.1 \mathrm{~kb}$. Although not shown, replacement of Pab-polD optimal buffer conditions by Taq-polA or Pab-polB reaction buffer did not improve the yield of amplified 1.95$2.95 \mathrm{~kb}$ DNA targets, nor enhanced the synthesis of longer PCR products.

\section{PCR AMPLIFICATION IN THE PRESENCE OF PRIMER MISMATCHES}

Complete $3^{\prime}$-terminal primer annealing to its complementary target sequence is a very important factor for the success and stringency of PCR (Petruska et al., 1988; Ishii and Fukui, 2001; Sipos et al., 2007). To evaluate the impact of primer mismatches on PCR efficiency and specificity by Pab-polD, forward primer sets containing up to four mismatches at the $3^{\prime}$-end have been designed for full amplification of the $0.5 \mathrm{~kb}$ DNA target from genomic DNA (Table 1). As shown in Figure 6A, specific amplification of the $0.5 \mathrm{~kb}$ DNA target could be achieved in the presence of either one or two $3^{\prime}$-end terminal mismatches, with lower PCR efficiency observed with two mismatches ( $\sim 5 \%$ remaining activity). The presence of three or four mismatches had a detrimental effect on the extension efficiency by Pab-polD. TaqpolA DNA polymerase generated specific PCR products with only one mismatched primer termini and longer mismatches prevented successful PCR amplification (Figure 6C). Although strand extension, and hence PCR amplification efficiency, were influenced by multiple mismatches at the $3^{\prime}$ end of the primer, the detection of specific PCR products was never compromised for Pab-polB (Figure 6B). Here, the data pointed out that Pab-polD is a suitable enzyme for Taq-polA substitution when $3^{\prime}$-terminal mismatched primers are refractory to PCR amplification. 


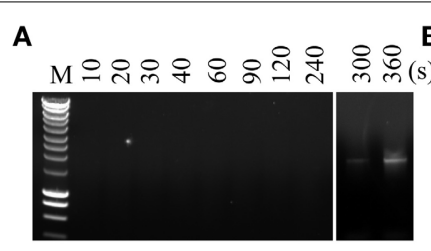

Pab-polD

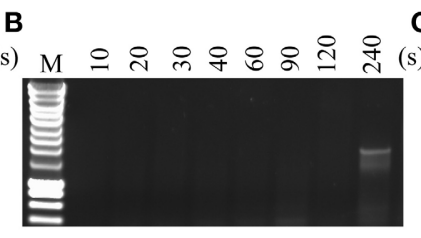

Isis
C

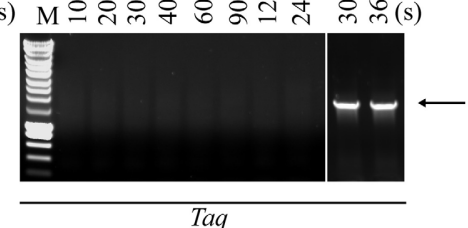

FIGURE 4 | Rate of DNA extension. PCR amplification of the $1.95 \mathrm{~kb}$ target (Table 1) was carried out with $0.1 \mathrm{U}$ of Pab-polD (A), $1 \mathrm{U}$ of Pab-polB (B), and $1 \mathrm{U}$ of Taq-polA (C) in their respective reaction buffer (Table 2). PCR program was
(2 min at $\left.94^{\circ} \mathrm{C}\right) \times 1 ;\left(1 \mathrm{~min}\right.$ at $94^{\circ} \mathrm{C}, 1 \mathrm{~min}$ at $58^{\circ} \mathrm{C}$, varying times in seconds as indicated at $\left.72^{\circ} \mathrm{C}\right) \times 30$. Molecular weight markers (M) are SmartLadder LF from Eurogentec. The arrow indicates the specific $1.95 \mathrm{~kb}$ band.
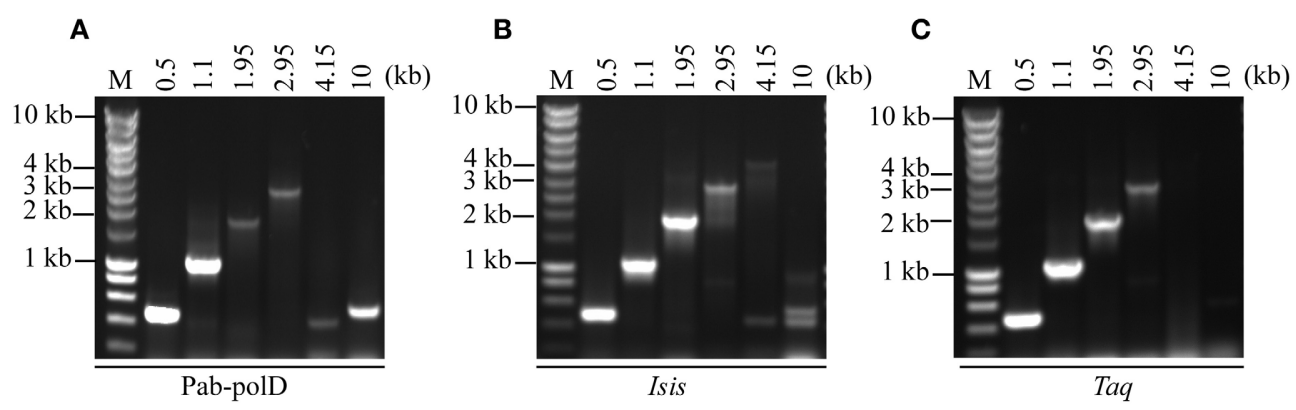

FIGURE 5 | PCR amplification of DNA fragments of various lengths. PCR reactions were carried out using $100 \mathrm{ng}$ of genomic DNA with 0.1 Uof Pab-polD (A), $1 \mathrm{U}$ of Pab-polB (B), and $1 \mathrm{U}$ of Taq-polA (C) in their respective reaction buffer (Table 2). Primer sets were chosen to amplify 0.5, 1.1, 1.95,
$2.95,4.15$, and $10 \mathrm{~kb}$ (Table 1). PCR programs were $\left(2 \mathrm{~min}\right.$ at $\left.94^{\circ} \mathrm{C}\right) \times 1$; $\left(1 \mathrm{~min}\right.$ at $94^{\circ} \mathrm{C} / 1 \mathrm{~min}$ at $58^{\circ} \mathrm{C} / 2,4,6,8,11$, and 16 min with respect to the target length at $\left.72^{\circ} \mathrm{C}\right) \times 30$. Molecular weight markers $(\mathrm{M})$ are SmartLadder LF from Eurogentec.

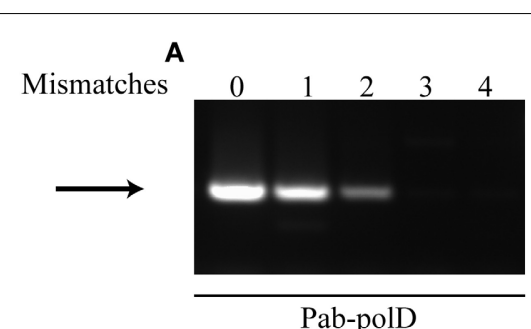

Pab-polD
B

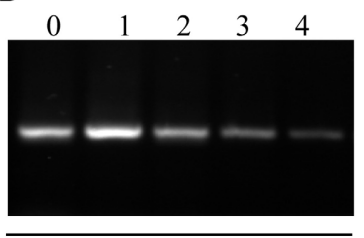

Isis
C

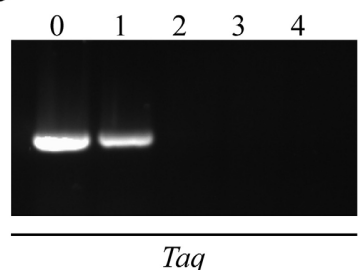

FIGURE 6 | PCR amplification in the presence of primer mismatches. PCR amplification of the $0.5 \mathrm{~kb}$ target (Table 1 ) was carried out with 0.1 $U$ of Pab-polD (A), $1 \mathrm{U}$ of Pab-polB (B), and $1 \mathrm{U}$ of Taq-polA (C) in their respective reaction buffer (Table 2). Primer sets were chosen to introduce $0,1,2,3$, and 4 mismatches at the $3^{\prime}$-termini of the forward primer (Table 1). PCR program was $\left(2 \mathrm{~min}\right.$ at $\left.94^{\circ} \mathrm{C}\right) \times 1 ;\left(1 \mathrm{~min}\right.$ at $94^{\circ} \mathrm{C}$, $1 \mathrm{~min}$ at $58^{\circ} \mathrm{C}, 2 \mathrm{~min}$ at $\left.72^{\circ} \mathrm{C}\right) \times 30 ;\left(5 \mathrm{~min}\right.$ at $\left.72^{\circ} \mathrm{C}\right) \times 1$. The arrow indicates the specific $0.5 \mathrm{~kb}$ band.

\section{PCR AMPLIFICATION IN THE PRESENCE OF KNOWN PCR INHIBITORS}

To investigate the impact of known PCR inhibitors (Al-Soud and Radstrom, 1998, 2001; Schrader et al., 2012), the $0.5 \mathrm{~kb}$ target was amplified from genomic DNA in reactions containing various levels of PCR-inhibiting compounds. The results are presented in Table 3. It was found that the variation of the ionic strength affected the PCR performances of the three different DNA polymerases. Indeed, Pab-polD was more resistant to $\mathrm{NaCl}$ ions than were Pab-polB and Taq-polA. In the conditions tested, a specific PCR product was detectable at the permissive concentration of $50 \mathrm{mM}$ with Pab-polD, while absent with Pab-polB and Taq-polA (Supplementary Figure 1). When SDS (Sodium Dodecyl Sulfate), the anionic reagent well-known for its protein-denaturing effects, was employed at a concentration of $0.02 \%$, PCR amplification was successful with Pab-polD and Pab-polB (Table 3); however, the yield of PCR products was dramatically impaired (Supplementary Figure 1). In comparison, Taq-polA was weakly active at a SDS concentration of $0.01 \% . \mathrm{CaCl}_{2}$, a potent PCR inhibitor (Bickley et al., 1996; Al-Soud and Radstrom, 1998) found for instance in milk, cheese, or bones, was found to impede the amplification of the specific $0.5 \mathrm{~kb}$ target when incubated at a concentration of $2 \mathrm{mM}$ for Pab-polD and Taq-polA (Table 3). Family B DNA polymerase was highly sensitive to $\mathrm{CaCl}_{2}$ as observed the severe reduction in PCR activity at a final concentration of $1 \mathrm{mM}$ (Supplementary Figure 1).

It has been reported that heme compounds, for instance hemoglobin and hematin, yielded interferences in PCR amplifications (Akane et al., 1994). For these reasons, we investigated 
Pab-polD PCR performances in the presence of these two bloodsubstances. Interestingly, hemoglobin never altered PCR specificity and efficiency by Pab-PolD and Pab-polB even at a final concentration of $13 \mathrm{mg} / \mathrm{ml}$ (Supplementary Figure 1). However, PCR performances by Taq-polA were entirely compromised at the minimal concentrations of $1.75-3.5 \mathrm{mg} / \mathrm{ml}$. Hematin decreased the yield of PCR products by Pab-polD and Taq-polA when present at a final concentration of $12.5 \mu \mathrm{M}$, while Pab-polB still retained significant activity in the presence of $>25 \mu \mathrm{M}$ of hematin.

The blood anticoagulant substance heparin described to inhibit PCR (Yokota et al., 1999) has been investigated. In the PCR reactions, the addition of heparin suppressed the formation of a specific PCR product in a dose-dependent fashion (from 0.006 to $0.2 \mathrm{U} / \mu \mathrm{l}$ ) for all three PCR enzymes. Moreover, EDTA (EthyleneDiamineTetraAcetic acid), used also as a common anticoagulant to treat blood samples, and included in several elution buffers of nucleic acid purification, has been described to interfere with PCR (Yokota et al., 1999). In this study, EDTA had an inhibitory effect at a concentration greater than $0.5 \mathrm{mM}$ for all three PCR enzymes. This result is likely indicative of the chelation of $\mathrm{Mg}^{2+}$ ions present in reaction buffers of each DNA polymerase, therefore compromising DNA amplification.

Since urea has been identified as the main component of urine that inhibits PCR (Khan et al., 1991), we challenged Pab-polD, Pab-polB, and Taq-polA in its presence. As shown in Table 3, Pab-polB was the most resistant DNA polymerase, specifically amplifying the $0.5 \mathrm{~kb}$ target even at the highest concentration of $100 \mathrm{mM}$. Pab-polD and Taq-polA showed inhibitory concentrations $>25$ and $50 \mathrm{mM}$, respectively. Humic acid, representative of environmental samples (e.g., soil, water, and dead matter), has been recognized as an efficient PCR inhibitor even at low concentrations (Tsai and Olson, 1992; Ijzerman et al., 1997). For this reason, all three enzymes have been submitted to PCR amplification with increasing amounts of humic acid (15-250 ng/ $\mu \mathrm{l}$ ). No PCR product was visible with Pab-polD, even at the lowest

Table 3 | Potential inhibitory effects of organic and inorganic substances on PCR.

\begin{tabular}{lccc}
\hline & \multicolumn{3}{c}{$\begin{array}{c}\text { Inhibitory concentration } \\
\text { of compounds }\end{array}$} \\
\cline { 2 - 4 } & Pab-polD & Pab-polB & Taq-polA \\
\hline $\mathrm{NaCl}(\mathrm{mM})$ & $>50$ & $>25$ & $>25$ \\
$\mathrm{SDS} \%(\mathrm{w} / \mathrm{v})$ & $>0.02$ & $>0.02$ & $>0.01$ \\
$\mathrm{CaCl}(\mathrm{mM})$ & $>2$ & $>1$ & $>2$ \\
Hemoglobin $(\mathrm{mg} / \mathrm{ml})$ & $>13$ & $>13$ & $>3.5$ \\
Hematin $(\mu \mathrm{M})$ & $>12.5$ & $>25$ & $>12.5$ \\
Heparin $(\mathrm{U} / \mathrm{ml})$ & - & - & $>0.5$ \\
EDTA $(\mathrm{mM})$ & $>0.5$ & $>0.5$ & $>50$ \\
Urea $(\mathrm{mM})$ & $>25$ & $>100$ & $>15$ \\
Humic acid $(\mathrm{ng} / \mu \mathrm{l})$ & - & $>62$ & $>0.4$ \\
Phenol \% $(\mathrm{v} / \mathrm{v})$ & $>0.6$ & $>0.8$ & $>4$ \\
Ethanol \% $(\mathrm{v} / \mathrm{v})$ & $>4$ & $>5$ & $>2$ \\
Isopropanol \% $(\mathrm{v} / \mathrm{v})$ & $>2$ & $>8$ &
\end{tabular}

concentration. PCR amplification with Taq-polA was positive up to a humic acid concentration of $15 \mathrm{ng} / \mu \mathrm{l}$. Pab-polB was the most resistant since it could PCR amplify the $0.5 \mathrm{~kb}$ target at $62.5 \mathrm{ng} / \mu \mathrm{l}$ of humic acid (Table 3 ).

Phenol, ethanol, and isopropanol are common organic substances used in the procedure for genomic extraction (Charbonnier et al., 1995) and relevant of food and environmental samples (Wilson, 1997). Interestingly, PCR performances of family B DNA polymerase were never affected by the varying concentrations of the three organic compounds (Supplementary Figure 1). In contrast, Taq-polA and Pab-polD exhibited similar inhibitory concentrations of isopropanol and ethanol ( $>2$ and $>4 \%$, respectively). Moreover, Pab-polD was more tolerant to PCR inhibition by phenol than Taq-polA (Table 3). Overall, this comparative study clearly revealed that Pab-polB is the most tolerant enzyme to PCR inhibitors. Pab-polD seems to have a higher resistance to particular PCR inhibitors than Taq-polA (e.g., NaCl, SDS, Phenol, and hemoglobin), although sharing similar sensitivity (EDTA, ethanol, isopropanol, calcium, hematin, heparin). Finally, TaqpolA exhibited superior resistance to humic acid and urea than Pab-polD.

\section{DISCUSSION}

The family D DNA polymerase from $P$. abyssi has been applied to PCR on genomic DNA and submitted to varying chemical parameters in order to evaluate its performance. For this purpose, a buffer has been optimized using the Pab-polB reaction buffer as a starting point due to this family B DNA polymerase originated from the same archaeon, $P$. abyssi. Here, we show for the first time that a family D DNA polymerase is functional in PCR amplification of a $0.5 \mathrm{~kb}$ DNA target. Under the conditions listed in Table 1, the three enzymes were analyzed to compare thermal resistance. Pab-polD was identified as more resistant than Taq-polA, yet not as robust as Pab-polB to the increased thermal denaturation during cycling (Table 2). These data obtained for the commercial enzymes being comparable with that already published (Gueguen et al., 2001; Dietrich et al., 2002) (Supplementary Figure 2) clearly suggest that Pab-polD is a thermostable enzyme. These results are interesting since they indicate that denaturation temperature during cycling can be increased when required during PCR. This is particularly useful when genomic DNA contains secondary structures or high GC-rich regions.

As expected, for all three enzymes PCR efficiency was variable in respect to the concentration of the 1.7 million base-pair genomic DNA, with $0.5 \mathrm{ng}$ being the permissive amount for Pab-polB, while Pab-polD and Taq-polA were more sensitive to template dilution. PCR analysis of trace amounts of DNA has become an important concern in forensic investigations (Van Oorschot et al., 2010). While some laboratories set up $0.2 \mathrm{ng}$ as a threshold limit for reliability of the investigations (Budowle et al., 2009), others continue to revise this limit (Kaminiwa et al., 2013). In our conditions, Pab-polD did not behave as an effective tool for the amplification of limited amounts of genomic DNA. Therefore, increasing the number of cycles or varying some compounds within the reaction buffer can be a useful alternative to overcome the limits (Van Oorschot et al., 2010). 
In this study, the highest amount of genomic DNA has been applied to all PCR experiments and in these conditions the $0.5 \mathrm{~kb}$ target was significantly amplified by Pab-polD, Pab-polB, and Taq-polA. However, upon increasing the length of the target, the differences in PCR performance became more obvious (Pab-polB $>$ Taq-polA $>$ Pab-polD). A maximum of length of $2.95 \mathrm{~kb}$ was produced by Taq-polA and Pab-polD. Although barely detectable, Pab-polB could amplify the $4.15 \mathrm{~kb}$ target. The difficulty of PabpolD to PCR amplify long DNA fragments was not due to a high GC content of the DNA regions since all exhibited a value below $48 \%$ (Table 1). Pab-polD is known to be endowed with lower processivity than Pab-polB, requiring the PCNA (Proliferating Cell Nuclear Antigen) clamp for robust DNA synthesis (Henneke et al., 2005). Thus, further optimization of PCR amplification of large DNA fragments is certainly possible, for instance, by altering the reaction buffer components, adding PCNA or mixing the two Pab PCR enzymes.

Full annealing between primer and template sequences is generally considered crucial for the specific amplification of a nucleic acid sequence (Ghadessy et al., 2004). PCR-based amplification of specific sequences is essential in detecting single nucleotide polymorphisms (SNPs), in identifying microbial-archaeal populations and in diagnostics (Sipos et al., 2007; Liu et al., 2012). In these approaches, "universal" primer sets are used with the possibility to induce the formation of mismatched base pairs at template-primer $3^{\prime}$-termini. As a result, PCR amplification is reduced or fully inhibited (Huang et al., 1992), depending on the length of base mispairs. In our study, Pab-polD was challenged in PCR with mismatched base pairs $(1,2,3$, and 4 base mispairs) at template-primer $3^{\prime}$-termini. Pab-polD could amplify the $0.5 \mathrm{~kb}$ DNA target despite the presence of 2 mismatches but with reduced efficiency. Taq-polA retains activity in the presence of 1 mismatch at the $3^{\prime}$-terminus as already published (Huang et al., 1992) but was inhibited by two mismatches. Pab-polB was functional even in the presence of 4 mismatches. The PabPCR enzymes show a higher tolerance to the presence of mismatches which must be attributed to their associated $33^{\prime}-5^{\prime}$ exonuclease function as already compared (Gueguen et al., 2001). Up to four and two mismatches can be accommodated into the exonuclease active site of Pab-polB and Pab-polD, respectively, which subsequently induce the degradation of the $3^{\prime}$-termini. Families $B$ and D from $P f u$ are also known to efficiently process $3^{\prime}$-end termini of primers (Richardson et al., 2013a,b).

Time-dependent PCR extension has been carried out with Pab-polD and compared to Pab-polB and Taq-polA. A PCR product of constant length $(1.95 \mathrm{~kb})$ was amplified by increasing the extension time. Under these conditions, Pab-polD was the slowest enzyme able to generate the $1.95 \mathrm{~kb}$ target in $6 \mathrm{~min}$ whereas 5 and 4 min where required respectively for Taq-polA and PabpolB. The calculated extension rate of Pab-polD was $0.33 \mathrm{~kb} / \mathrm{min}$. This is almost comparable with the value of $0.39 \mathrm{~kb} / \mathrm{min}$ for TaqpolA and slightly lower to that of $0.48 \mathrm{~kb} / \mathrm{min}$ for Pab-polB. The values confirmed that Pab-polB, like other family B DNA polymerases, e.g., $P f u$ and $T f u$, are particularly slow enzymes (Perler et al., 1996; Terpe, 2013). Although the extension rate has been determined by conventional end-point PCR which is not the method of choice compared to real-time quantitative PCR (Arezi et al., 2003), Pab-polD also shows a reduced elongation rate in PCR. In Pab-polB, and potentially Pab-polD, this property could be explained by the slow kinetic partitioning of the primer in the exonuclease and polymerase active sites allowing the DNA polymerase to proofread the nucleotide incorporation events, and when required to remove the misincorporated base (Gouge et al., 2012). On the other hand, the presence of secondary structures could also impede the efficiency of DNA synthesis by the Pyrococcus enzymes (Henneke, 2012).

The negative effect of inorganic and organic substances on PCR efficiency and specificity by Pab-polD along with PabpolB and Taq-polA has been investigated. The DNA polymerase the most resistant to ions $\mathrm{NaCl}$ and $\mathrm{CaCl}_{2}$ was $\mathrm{Pab}$-polD. This higher resistance to elevated $\mathrm{NaCl}$ concentrations is similar to that found for some bacterial and archaeal PCR enzymes investigated previously (Al-Soud and Radstrom, 1998). The highest tolerance to calcium ions compared to other thermostable DNA polymerases (Al-Soud and Radstrom, 1998) places Pab-polD as a suitable enzyme in the amplification of food (e.g., milk and cheese) and human samples (e.g., teeth and bones) for instance. Introduced during the procedure of genomic extraction or naturally present in food and in environmental samples (Charbonnier et al., 1995; Wilson, 1997), phenolic compounds (Ethanol, phenol, and isopropanol) reduced the PCR performance of Pab-polD. These negative effects are commonly observed with most PCR enzymes (Rossen et al., 1992), except for Pab-polB (shown in this study) and Tth (Thermus thermophilus) (Katcher and Schwartz, 1994). Compounds, such as the SDS anionic detergent and EDTA, known to have direct and indirect negative effects on proteins, respectively, did not dramatically impact on PCR performances by Pab-polD compared to Pab-polB. Surprisingly, the permissive concentration of the two compounds for Taq-polA were slightly different to those found in another study (Yang et al., 2007), indicating that the source of the enzyme, the DNA target to be amplified and the reaction conditions are important parameters impacting on the issue of the investigation. The inhibitory activity of urea in PCR was observed with Pab-polD at a lower concentration threshold compared to Taq-polA or Pab-polB, and the values obtained with Taq-polA confirmed those previously published (Khan et al., 1991). Organic substances like heparin or humic acid were completely inhibitory to PCR reactions by Pab-polD. The strong inhibitory effect of heparin on all three PCR enzymes has been observed with other thermostable DNA polymerases (Yokota et al., 1999). This is not so surprising since heparin is commonly used as a trapping agent of DNA polymerases in both polymerase assays and chromatography. The effects of two heme blood substances, hemoglobin and hematin, did not impact similarly on PCR performances by Pab-polD. While completely resistant to hemoglobin, Pab-polD was sensitive to hematin but to the same level as Taq-polA. Generally, inhibitory effects by heme compounds appear as a drawback in PCR with thresholds dependent on the PCR enzymes used (Akane et al., 1994; Al-Soud and Radstrom, 2001). In this study, Taq-polA was the most sensitive to hemoglobin.

In conclusion, our results demonstrated for the first time that an archaeal family D DNA polymerase is functional in PCR. PCR performances (rate of DNA synthesis, maximal length of 
amplification, minimal input genomic DNA, resistance to thermal denaturation during cycling, and PCR amplifications with $3^{\prime}$-end mismatched primers) of Pab-polD appears more comparable to Taq-polA than Pab-polB, but with some valuable properties (e.g., high resistance to thermal denaturation during cycling, amplification with primers containing up to 2 mismatches). In addition, due to its superior resistance to inhibitors than Taq-polA (e.g., calcium ions, sodium chloride, hemoglobin, SDS), Pab-polD could replace the enzyme in some applications. Additional investigations (e.g., PCR fidelity, ability to specifically amplify high GC rich content and degraded genomic DNA) are now required to consider Pab-polD as a suitable PCR enzyme that could overcome the handicap encounter by conventional enzymes that are marketed for PCR.

\section{ACKNOWLEDGMENTS}

The work was financially supported by the French National Research Agency (ANR-10-JCJC-1501-01 to Ghislaine Henneke) and the General Council of Finistère (CG29). I would like to thank Sébastien Le Laz for help with PCR optimization.

\section{SUPPLEMENTARY MATERIAL}

The Supplementary Material for this article can be found online at: http://www.frontiersin.org/journal/10.3389/fmicb.2014. 00195/abstract

\section{REFERENCES}

Akane, A., Matsubara, K., Nakamura, H., Takahashi, S., and Kimura, K. (1994). Identification of the heme compound copurified with deoxyribonucleic acid (DNA) from bloodstains, a major inhibitor of polymerase chain reaction (PCR) amplification. J. Forensic Sci. 39, 362-372.

Al-Soud, W. A., and Radstrom, P. (1998). Capacity of nine thermostable DNA polymerases To mediate DNA amplification in the presence of PCR-inhibiting samples. Appl. Environ. Microbiol. 64, 3748-3753.

Al-Soud, W. A., and Radstrom, P. (2001). Purification and characterization of PCR-inhibitory components in blood cells. J. Clin. Microbiol. 39, 485-493. doi: 10.1128/JCM.39.2.485-493.2001

Arezi, B., Xing, W., Sorge, J. A., and Hogrefe, H. H. (2003). Amplification efficiency of thermostable DNA polymerases. Anal. Biochem. 321, 226-235. doi: 10.1016/S0003-2697(03)00465-2

Bickley, J., Short, J. K., McDowell, D. G., and Parkes, H. C. (1996). Polymerase chain reaction (PCR) detection of Listeria monocytogenes in diluted milk and reversal of PCR inhibition caused by calcium ions. Lett. Appl. Microbiol. 22, 153-158. doi: 10.1111/j.1472-765X.1996.tb01131

Biles, B. D., and Connolly, B. A. (2004). Low-fidelity Pyrococcus furiosus DNA polymerase mutants useful in error-prone PCR. Nucleic Acids Res. 32, e176. doi: 10.1093/nar/gnh174

Braithwaite, D. K., and Ito, J. (1993). Compilation, alignment, and phylogenetic relationships of DNA polymerases. Nucleic Acids Res. 21, 787-802. doi: 10.1093/nar/21.4.787

Budowle, B., Eisenberg, A. J., and Van Daal, A. (2009). Validity of low copy number typing and applications to forensic science. Croat. Med. J. 50, 207-217. doi: 10.3325/cmj.2009.50.207

Cambon-Bonavita, M. A., Schmitt, P., Zieger, M., Flaman, J. M., Lesongeur, F., Raguenes, G., et al. (2000). Cloning, expression, and characterization of DNA polymerase I from the hyperthermophilic archaea Thermococcus fumicolans. Extremophiles 4, 215-225. doi: 10.1007/PL00010714

Cann, I. K., and Ishino, Y. (1999). Archaeal DNA replication: identifying the pieces to solve a puzzle. Genetics 152, 1249-1267.

Cann, I. K., Komori, K., Toh, H., Kanai, S., and Ishino, Y. (1998). A heterodimeric DNA polymerase: evidence that members of Euryarchaeota possess a distinct DNA polymerase. Proc. Natl. Acad. Sci. U.S.A. 95, 14250-14255. doi: 10.1073/pnas.95.24.14250
Castrec, B., Laurent, S., Henneke, G., Flament, D., and Raffin, J. P. (2010). The glycine-rich motif of Pyrococcus abyssi DNA polymerase D is critical for protein stability. J. Mol. Biol. 396, 840-848. doi: 10.1016/j.jmb.2010. 01.006

Castrec, B., Rouillon, C., Henneke, G., Flament, D., Querellou, J., and Raffin, J. P. (2009). Binding to PCNA in Euryarchaeal DNA Replication requires two PIP motifs for DNA polymerase D and one PIP motif for DNA polymerase B. J. Mol. Biol. 394, 209-218. doi: 10.1016/j.jmb.2009.09.044

Charbonnier, F., Forterre, P., Erauso, G., and Prieur, D. (1995). "Purification of plasmids from thermophilic and hyperthermophilic archaea," in Archaea: A Laboratory Manual, eds A. R. Place and F. T. Robb (New York, NY: Cold Spring Harbor Laboratory Press), 87-90.

Chien, A., Edgar, D. B., and Trela, J. M. (1976). Deoxyribonucleic acid polymerase from the extreme thermophile Thermus aquaticus. J. Bacteriol. 127, 1550-1557.

Cline, J., Braman, J. C., and Hogrefe, H. H. (1996). PCR fidelity of pfu DNA polymerase and other thermostable DNA polymerases. Nucleic Acids Res. 24, 3546-3551. doi: 10.1093/nar/24.18.3546

Cubonova, L., Richardson, T., Burkhart, B. W., Kelman, Z., Connolly, B. A., Reeve, J. N., et al. (2013). Archaeal DNA polymerase D but not DNA polymerase B is required for genome replication in Thermococcus kodakarensis. J. Bacteriol. 195, 2322-2328. doi: 10.1128/JB.02037-12

Delarue, M., Poch, O., Tordo, N., Moras, D., and Argos, P. (1990). An attempt to unify the structure of polymerases. Protein Eng. 3, 461-467. doi: 10.1093/protein/3.6.461

Dietrich, J., Schmitt, P., Zieger, M., Preve, B., Rolland, J. L., Chaabihi, H., et al. (2002). PCR performance of the highly thermostable proof-reading B-type DNA polymerase from Pyrococcus abyssi. FEMS Microbiol. Lett. 217, 89-94. doi: 10.1016/S0378-1097(02)01037-6

Eckert, K. A., and Kunkel, T. A. (1991). DNA polymerase fidelity and the polymerase chain reaction. PCR Methods Appl. 1, 17-24.

Fogg, M. J., Pearl, L. H., and Connolly, B. A. (2002). Structural basis for uracil recognition by archaeal family B DNA polymerases. Nat. Struct. Biol. 9, 922-927. doi: $10.1038 / \mathrm{nsb} 867$

Ghadessy, F. J., Ramsay, N., Boudsocq, F., Loakes, D., Brown, A., Iwai, S., et al. (2004). Generic expansion of the substrate spectrum of a DNA polymerase by directed evolution. Nat. Biotechnol. 22, 755-759. doi: 10.1038/ nbt974

Gouge, J., Ralec, C., Henneke, G., and Delarue, M. (2012). Molecular recognition of canonical and deaminated bases by P. abyssi family B DNA polymerase. J. Mol. Biol. 423, 315-336. doi: 10.1016/j.jmb.2012.07.025

Gueguen, Y., Rolland, J. L., Lecompte, O., Azam, P., Le Romancer, G., Flament, D., et al. (2001). Characterization of two DNA polymerases from the hyperthermophilic euryarchaeon Pyrococcus abyssi. Eur. J. Biochem. 268, 5961-5969. doi: 10.1046/j.0014-2956.2001.02550.x

Henneke, G. (2012). In vitro reconstitution of RNA primer removal in Archaea reveals the existence of two pathways. Biochem. J. 447, 271-280. doi: 10.1042/BJ20120959.

Henneke, G., Flament, D., Hubscher, U., Querellou, J., and Raffin, J. P. (2005). The hyperthermophilic euryarchaeota Pyrococcus abyssi likely requires the two DNA polymerases D and B for DNA replication. J. Mol. Biol. 350, 53-64. doi: 10.1016/j.jmb.2005.04.042

Hogrefe, H. H., Cline, J., Lovejoy, A. E., and Nielson, K. B. (2001). DNA polymerases from hyperthermophiles. Methods Enzymol. 334, 91-116. doi: 10.1016/S0076-6879(01)34461-0

Huang, M. M., Arnheim, N., and Goodman, M. F. (1992). Extension of base mispairs by Taq DNA polymerase: implications for single nucleotide discrimination in PCR. Nucleic Acids Res. 20, 4567-4573. doi: 10.1093/nar/20.17.4567

Hubscher, U., Spadari, S., Villani, G., and Maga, G. (2010). DNA Polymerases: Discovery, Characterization and Functions in Cellular DNA Transactions. Singapore: World Scientific Publishing Co. Pte. Ltd.

Ijzerman, M. M., Dahling, D. R., and Fout, G. S. (1997). A method to remove environmental inhibitors prior to the detection of waterborne enteric viruses by reverse transcription-polymerase chain reaction. J. Virol. Methods 63, 145-153. doi: 10.1016/S0166-0934(96)02123-4

Ishii, K., and Fukui, M. (2001). Optimization of annealing temperature to reduce bias caused by a primer mismatch in multitemplate PCR. Appl. Environ. Microbiol. 67, 3753-3755. doi: 10.1128/AEM.67.8.3753-3755.2001

Ishino, Y., Komori, K., Cann, I. K., and Koga, Y. (1998). A novel DNA polymerase family found in Archaea. J. Bacteriol. 180, 2232-2236. 
Joyce, C. M., and Steitz, T. A. (1994). Function and structure relationships in DNA polymerases. Annu. Rev. Biochem. 63, 777-822. doi: 10.1146/annurev.bi.63.070194.004021

Kaminiwa, J., Honda, K., Sugano, Y., Yano, S., Nishi, T., and Sekine, Y. (2013). Vanadium accelerates polymerase chain reaction and expands the applicability of forensic DNA testing. J. Forensic Leg. Med. 20, 326-333. doi:10.1016/j.jflm.2012.09.006.

Katcher, H. L., and Schwartz, I. (1994). A distinctive property of Tth DNA polymerase: enzymatic amplification in the presence of phenol. Biotechniques 16, 84-92

Khan, G., Kangro, H. O., Coates, P. J., and Heath, R. B. (1991). Inhibitory effects of urine on the polymerase chain reaction for cytomegalovirus DNA. J. Clin. Pathol. 44, 360-365. doi: 10.1136/jcp.44.5.360

Kong, H., Kucera, R. B., and Jack, W. E. (1993). Characterization of a DNA polymerase from the hyperthermophile archaea Thermococcus litoralis. Vent DNA polymerase, steady state kinetics, thermal stability, processivity, strand displacement, and exonuclease activities. J. Biol. Chem. 268, 1965-1975.

Kornberg, A., and Baker, T. A. (1992). DNA Replication. New York, NY: W. H. Freeman and Company.

Langhorst, B. W., Jack, W. E., Reha-Krantz, L., and Nichols, N. M. (2012). Polbase: a repository of biochemical, genetic and structural information about DNA polymerases. Nucleic Acids Res. 40, D381-387. doi: 10.1093/nar/ gkr847

Lawyer, F. C., Stoffel, S., Saiki, R. K., Chang, S. Y., Landre, P. A., Abramson, R. D., et al. (1993). High-level expression, purification, and enzymatic characterization of full-length Thermus aquaticus DNA polymerase and a truncated form deficient in $5^{\prime}$ to $3^{\prime}$ exonuclease activity. PCR Methods Appl. 2, 275-287.

Le, Y., Chen, H., Zagursky, R., Wu, J. H., and Shao, W. (2013). Thermostable DNA ligase-mediated PCR production of circular plasmid (PPCP) and its application in directed evolution via in situ error-prone PCR. DNA Res. 20, 375-382. doi: $10.1093 /$ dnares/dst016

Lipps, G., Rother, S., Hart, C., and Krauss, G. (2003). A novel type of replicative enzyme harbouring ATPase, primase and DNA polymerase activity. EMBO J. 22, 2516-2525. doi: 10.1093/emboj/cdg246

Liu, J., Huang, S., Sun, M., Liu, S., Liu, Y., Wang, W., et al. (2012). An improved allele-specific PCR primer design method for SNP marker analysis and its application. Plant Methods 8, 34. doi: 10.1186/1746-4811-8-34

Macneill, S. A., Baldacci, G., Burgers, P. M., and Hubscher, U. (2001). A unified nomenclature for the subunits of eukaryotic DNA polymerase delta. Trends Biochem. Sci. 26, 16-17. doi: 10.1016/S0968-0004(00)01709-6

Marsic, D., Flaman, J. M., and Ng, J. D. (2008). New DNA polymerase from the hyperthermophilic marine archaeon Thermococcus thioreducens. Extremophiles 12, 775-788. doi: 10.1007/s00792-008-0181-7

Matsui, I., Urushibata, Y., Shen, Y., Matsui, E., and Yokoyama, H. (2011). Novel structure of an $\mathrm{N}$-terminal domain that is crucial for the dimeric assembly and DNA-binding of an archaeal DNA polymerase D large subunit from Pyrococcus horikoshii. FEBS Lett. 585, 452-458. doi: 10.1016/j.febslet.2010. 12.040

McCullum, E. O., Williams, B. A., Zhang, J., and Chaput, J. C. (2010). Random mutagenesis by error-prone PCR. Methods Mol. Biol. 634, 103-109. doi: 10.1007/978-1-60761-652-8_7

McDonald, J. P., Hall, A., Gasparutto, D., Cadet, J., Ballantyne, J., and Woodgate, R. (2006). Novel thermostable Y-family polymerases: applications for the PCR amplification of damaged or ancient DNAs. Nucleic Acids Res. 34, 1102-1111. doi: 10.1093/nar/gkj512

Moussard, H., Henneke, G., Moreira, D., Jouffe, V., Lopez-Garcia, P., and Jeanthon, C. (2006). Thermophilic lifestyle for an uncultured archaeon from hydrothermal vents: evidence from environmental genomics. Appl. Environ. Microbiol. 72, 2268-2271. doi: 10.1128/AEM.72.3.2268-2271.2006

Ohmori, H., Friedberg, E. C., Fuchs, R. P., Goodman, M. F., Hanaoka, F., Hinkle, D., et al. (2001). The Y-family of DNA polymerases. Mol. Cell 8, 7-8. doi: 10.1016/S1097-2765(01)00278-7

Palud, A., Villani, G., L’Haridon, S., Querellou, J., Raffin, J. P., and Henneke, G. (2008). Intrinsic properties of the two replicative DNA polymerases of Pyrococcus abyssi in replicating abasic sites: possible role in DNA damage tolerance? Mol. Microbiol. 70, 746-761. doi: 10.1111/j.1365-2958.2008. 06446.x
Pavlov, A. R., Pavlova, N. V., Kozyavkin, S. A., and Slesarev, A. I. (2004). Recent developments in the optimization of thermostable DNA polymerases for efficient applications. Trends Biotechnol. 22, 253-260. doi: 10.1016/j.tibtech.2004.02.011

Perler, F. B., Kumar, S., and Kong, H. (1996). Thermostable DNA polymerases. Adv. Protein Chem. 48, 377-435. doi: 10.1016/S0065-3233(08)60367-8

Petruska, J., Goodman, M. F., Boosalis, M. S., Sowers, L. C., Cheong, C., and Tinoco, I. Jr. (1988). Comparison between DNA melting thermodynamics and DNA polymerase fidelity. Proc. Natl. Acad. Sci. U.S.A. 85, 6252-6256. doi: 10.1073/pnas.85.17.6252

Richardson, T. T., Gilroy, L., Ishino, Y., Connolly, B. A., and Henneke, G. (2013a). Novel inhibition of archaeal family-D DNA polymerase by uracil. Nucleic Acids Res. 41, 4207-4218. doi: 10.1093/nar/gkt083

Richardson, T. T., Wu, X., Keith, B. J., Heslop, P., Jones, A. C., and Connolly, B. A. (2013b). Unwinding of primer-templates by archaeal family-B DNA polymerases in response to template-strand uracil. Nucleic Acids Res. 41, 2466-2478. doi: 10.1093/nar/gks1364

Rossen, L., Norskov, P., Holmstrom, K., and Rasmussen, O. F. (1992). Inhibition of PCR by components of food samples, microbial diagnostic assays and DNA-extraction solutions. Int. J. Food Microbiol. 17, 37-45. doi: 10.1016/01681605(92)90017-W

Rothwell, P. J., and Waksman, G. (2005). Structure and mechanism of DNA polymerases. Adv. Protein Chem. 71, 401-440. doi: 10.1016/S0065-3233(04)71011-6

Rouillon, C., Henneke, G., Flament, D., Querellou, J., and Raffin, J. P. (2007). DNA polymerase switching on homotrimeric PCNA at the replication fork of the euryarchaea Pyrococcus abyssi. J. Mol. Biol. 369, 343-355. doi: 10.1016/j.jmb.2007.03.054

Saiki, R. K., Scharf, S., Faloona, F., Mullis, K. B., Horn, G. T., Erlich, H. A., et al. (1985). Enzymatic amplification of beta-globin genomic sequences and restriction site analysis for diagnosis of sickle cell anemia. Science 230, 1350-1354. doi: $10.1126 /$ science. 2999980

Schrader, C., Schielke, A., Ellerbroek, L., and Johne, R. (2012). PCR inhibitors occurrence, properties and removal. J. Appl. Microbiol. 113, 1014-1026. doi: 10.1111/j.1365-2672.2012.05384.x

Sharkey, D. J., Scalice, E. R., Christy, K. G. Jr., Atwood, S. M., and Daiss, J. L. (1994). Antibodies as thermolabile switches: high temperature triggering for the polymerase chain reaction. Biotechnology (N.Y.) 12, 506-509. doi: 10.1038/nbt0594-506

Shen, Y., Musti, K., Hiramoto, M., Kikuchi, H., Kawarabayashi, Y., and Matsui, I. (2001). Invariant Asp-1122 and Asp-1124 are essential residues for polymerization catalysis of family D DNA polymerase from Pyrococcus horikoshii. J. Biol. Chem. 276, 27376-27383. doi: 10.1074/jbc.M011762200

Sipos, R., Szekely, A. J., Palatinszky, M., Revesz, S., Marialigeti, K., and Nikolausz, M. (2007). Effect of primer mismatch, annealing temperature and PCR cycle number on 16S rRNA gene-targetting bacterial community analysis. FEMS Microbiol. Ecol. 60, 341-350. doi: 10.1111/j.1574-6941.2007. 00283.x

Takagi, M., Nishioka, M., Kakihara, H., Kitabayashi, M., Inoue, H., Kawakami, B., et al. (1997). Characterization of DNA polymerase from Pyrococcus sp. strain KOD1 and its application to PCR. Appl. Environ. Microbiol. 63, 4504-4510.

Terpe, K. (2013). Overview of thermostable DNA polymerases for classical PCR applications: from molecular and biochemical fundamentals to commercial systems. Appl. Microbiol. Biotechnol. 97, 10243-10254. doi: 10.1007/s00253-0135290-2

Tsai, Y. L., and Olson, B. H. (1992). Rapid method for separation of bacterial DNA from humic substances in sediments for polymerase chain reaction. Appl. Environ. Microbiol. 58, 2292-2295.

Uemori, T., Sato, Y., Kato, I., Doi, H., and Ishino, Y. (1997). A novel DNA polymerase in the hyperthermophilic archaeon, Pyrococcus furiosus: gene cloning, expression, and characterization. Genes Cells 2, 499-512. doi: 10.1046/j.13652443.1997.1380336.x

Van Oorschot, R. A., Ballantyne, K. N., and Mitchell, R. J. (2010). Forensic trace DNA: a review. Investig. Genet. 1, 14. doi: 10.1186/2041-2223-1-14

Wang, Y., Prosen, D. E., Mei, L., Sullivan, J. C., Finney, M., and Vander Horn, P. B. (2004). A novel strategy to engineer DNA polymerases for enhanced processivity and improved performance in vitro. Nucleic Acids Res. 32, 1197-1207. doi: $10.1093 / \mathrm{nar} / \mathrm{gkh} 271$

Wilson, I. G. (1997). Inhibition and facilitation of nucleic acid amplification. Appl. Environ. Microbiol. 63, 3741-3751. 
Wynne, S. A., Pinheiro, V. B., Holliger, P., and Leslie, A. G. (2013). Structures of an apo and a binary complex of an evolved archeal B family DNA polymerase capable of synthesising highly cy-dye labelled DNA. PLOS ONE 8:e70892. doi: 10.1371/journal.pone.0070892

Yamasaki, K., Urushibata, Y., Yamasaki, T., Arisaka, F., and Matsui, I. (2010). Solution structure of the N-terminal domain of the archaeal D-family DNA polymerase small subunit reveals evolutionary relationship to eukaryotic B-family polymerases. FEBS Lett. 584, 3370-3375. doi: 10.1016/j.febslet.2010.06.026

Yang, Y. G., Kim, J. Y., Song, Y. H., and Kim, D. S. (2007). A novel buffer system, AnyDirect, can improve polymerase chain reaction from whole blood without DNA isolation. Clin. Chim. Acta 380, 112-117. doi: 10.1016/j.cca.2007.01.019

Yokota, M., Tatsumi, N., Nathalang, O., Yamada, T., and Tsuda, I. (1999). Effects of heparin on polymerase chain reaction for blood white cells. J. Clin. Lab. Anal. 13, 133-140. doi: 10.1002/(SICI)1098-2825(1999)13:3<133::AIDJCLA $8>3.0$. CO;2-0
Conflict of Interest Statement: The authors declare that the research was conducted in the absence of any commercial or financial relationships that could be construed as a potential conflict of interest.

Received: 13 March 2014; accepted: 12 April 2014; published online: 07 May 2014. Citation: Killelea T, Ralec C, Bosse A and Henneke G (2014) PCR performance of a thermostable heterodimeric archaeal DNA polymerase. Front. Microbiol. 5:195. doi: 10.3389/fmicb.2014.00195

This article was submitted to Evolutionary and Genomic Microbiology, a section of the journal Frontiers in Microbiology.

Copyright (c) 2014 Killelea, Ralec, Bosse and Henneke. This is an open-access article distributed under the terms of the Creative Commons Attribution License (CC BY). The use, distribution or reproduction in other forums is permitted, provided the original author(s) or licensor are credited and that the original publication in this journal is cited, in accordance with accepted academic practice. No use, distribution or reproduction is permitted which does not comply with these terms. 